\title{
The Relationship between English Language Learners' Perceptions towards Classroom Oral Error Corrections and Their Pronunciation
} \section{Accuracy}

\author{
Afshin Peerdadeh Beiranvand $^{1} \&$ Ali Entezamara ${ }^{2}$ \\ ${ }^{1}$ Iran Language Institute, Technical and Vocational University, Khorramabad, Lorestan, Iran \\ ${ }^{2}$ Iran Language Institute, Borujerd Azad University, Khorramabad, Lorestan, Iran \\ Correspondence: Afshin Peerdadeh Beiranvand, Iran Language Institute (ILI), Technical and Vocational \\ University, Khorramabad, Lorestan, Iran. E-mail: afshin_peerdadeh@yahoo.com
}

Received: April 24, 2016 Accepted: August 8, 2016 Online Published: December 1, 2016

doi:10.5539/ijel.v6n7p1 URL: http://dx.doi.org/10.5539/ijel.v6n7p1

\begin{abstract}
Inevitably, language learners make mistakes, and teachers correct them. It is, also, crystal clear that language learners have different attitudes towards error and error correction strategies. Needless to say, language teachers' awareness of language learners' perceptions towards error and error correction strategies can heighten the quality and the quantity of language teaching and learning process. This study based on the findings of a questionnaire and a test given to 82 male and female English language learners in Iran Language Institute (ILI) investigates: 1) whether ILI English language learners have positive or negative attitudes towards classroom oral error corrections; 2) whether there is a relationship between ILI English language learners' perceptions towards classroom oral error corrections and their pronunciation accuracy; 3) if there is a relationship between ILI learners' gender and their attitudes towards classroom oral error corrections. The findings of this study show that ILI English language learners have absolutely positive attitudes towards classroom oral error corrections, which means they want to be corrected. The findings, also, show that there is not any significant relationship between ILI English language learners' perceptions towards classroom oral error corrections and their pronunciation accuracy. The findings, also, show that there is not any significant relationship between ILI English language learners' perceptions towards classroom oral error corrections and their gender.
\end{abstract}

Keywords: learner's perception, error correction, pronunciation accuracy, oral error

\section{Introduction}

English is the most international language in the world; in addition, it is the language of science, technology, and the internet. As you know, every day more and more people are added to the population of English language learners. We, also, know that it is not possible for most English language learners to acquire or learn English in real situations. As a result, they go to language schools and try to learn English through being taught in unreal situations or atmospheres. The situation is not only bad but also worse for the Iranian English language learners. It is worse because Iranian English language learners, in comparison, have fewer opportunities to come across and speak with English native speakers so that they are and can be seen as real foreign language learners. Needless to say, it is crystal clear that every year billions and billions of dollars is spent on English teaching and learning. Also, by taking in to account the amount of time spent on this issue, it is worth doing some more research in this area. Different teaching methods have been used in our classrooms. The methods have come and gone, maybe, because they have not been successful enough, or because better and newer methods have taken their places. I have written all this to show the importance of foreign language teaching and learning in general and English teaching and learning in particular. Moreover, I think there is still room for the improvement of English language teaching. As a matter of fact learning is always accompanied with errors and mistakes especially in the field of learning a foreign language. Fortunately, in this field, there are teachers to help language learners with their mistakes and errors. Without saying, it is known that most teachers have positive attitudes towards different error correction strategies. If they did not have positive attitudes towards error correction, they would not correct language learners. You know, "one of the most frustrating tasks for language teachers is that of correcting the same errors on and on. One possible explanation can be the different perceptions that teachers and 
learners have of the most adequate corrections of errors." (Lasagabaster \& Sierra, 2005). It is obvious that learners are different in their learning styles and preferences for instructional practices; therefore, teachers must try to make a match between their teaching styles and strategies and those of the students. By doing this, misunderstandings from both the students and the teachers' behaviors are prevented; as a result, both the quantity and quality of teaching and learning increase. Many language educators and researchers (Nunan, 1987; Horwits, 1988; Schulz, 2001) believe that matching the expectations of teachers and students is important for language learning. Nunan (1987) said, "One of the most serious blocks to learning is the mismatch between teachers and learners' expectations about what should happen in the classroom". Accordingly, teachers can benefit from discovering their students' preferences in instructional practices (Katayama, 2007). It is said that errors are inevitable in the process of learning, especially foreign language learning. H. Douglas Brown in his book (Principles of Language Learning and Teaching) writes, "Inevitably learners make mistakes in the process of acquisition, and that process will be impeded if they do not commit errors and benefit from various forms of feedback on those errors." So errors are important because they provide students with feedback from teachers' behalf. The attitudes of students towards a particular subject have implications on their achievement. Brian Tracy, in his book (Self-actualization and Individual Success), about the relationship between being successful and perceptions, writes, "There are no limits for achieving those goals and successes that you can achieve in your life except mental ones." Elsewhere, he says, "All causes and effects are mental, your thoughts will come in reality, your thoughts are creative, and you will become a person that you think about." He, also, says, "Your physical life is a representation of your inner life, and there is a direct relationship between the way you think, your inner emotion on one hand and your outer experience on the other hand." He, also, believes that human's way of acting is in harmony with their deepest believes. Elsewhere, he says that our subconscious mind causes our actions to happen in line with a model that is in harmony with our perceptions, attitudes, and believes. So we can say that our life is not separate from our mind and perception. I have written all this to say that the importance of perception is not something to be overlooked easily and heedlessly. A lot of researches about different types of oral error corrections and students' perceptions towards oral error corrections have been done all over the world. Kiptui \& Mbugua (2009) concluded that negative attitude towards English was one of the factors that affected academic achievement. Scott and his coworkers (2009) investigated the relationship between foreign language attitudes and reading and selling skills; they confirmed that they correlated mostly but significantly with foreign language attitudes and perceptions. The students with weaker reading and spelling scores showed more negative attitudes and perceptions towards foreign language. Mellet \& Crowe (2009) investigated the relationship between selected affective factors and achievement in English among secondary school students in Zimbabwe. Their study showed that the affective factors like attitudes towards English, students' self concept of academic ability, and students' perceptions of their English teachers correlated significantly with their academic achievement. Bidin (2009) did a correlation study on motivation and attitude towards learning English among university students in Malaysia. The purpose of the study was to describe the relationship between the students' motivation and attitudes towards their English language performance. Spearman rank order correlation coefficient test showed that there was a significant relationship between students' attitudes towards learning English and English language performance. Fakeye (2010) designed a correlation study to find out the relationship between students' personal variables such as attitude, academic ability, and their achievement in English language. The result of the study showed that there was a positive relationship between students' attitude and their language achievement. The findings of some other studies (e.g., Cathcart \& Olsen, 1976; Hawkey, 2006; McCargar, 1993; Nunan, 1988; Oladejo, 1993; Sculz, 1996, 2001) show differences between teachers' teaching preferences and learners' learning preferences. On the other hand, some language researchers and educators believe that a mismatch between teachers and learners' perceptions about the effectiveness of instructional practices can result in unsatisfactory learning outcomes (Nunan, 1987; Horwitz, 1988; Schulz, 2001). As a result, it is necessary and very helpful for teachers to discover their students' preferences in instructional practices. Nunan (1995) said, "Teachers should find out what their students think and feel about what and how they want to learn." Writing about errors, naturally, learners make mistakes, and their mistakes, errors, and feedback to errors have always been of great importance an interest to foreign language teachers and researchers. Katayama (2007) did a study in Japan about the students' perceptions towards oral error corrections. The study showed that the students had positive attitudes towards oral error corrections. As it was mentioned above, learners' perceptions towards learning, language, mistakes, corrections, and teachers are very important. Although a lot of studies have been done on these subjects, there are still gaps to be filled, for example learners "perceptions towards classroom oral error corrections and its relationship with learners" pronunciation accuracy. In this study, I have tried to do my bit by trying to find the answers to following questions. First, what are the perceptions and attitudes of Iranian English language learners towards oral error corrections? Second, what is the relationship between 
English language learners' perceptions and attitudes towards oral error corrections and their pronunciation accuracy? And, third, what is the relationship between gender and Iranian language learners' perceptions towards oral error correction? This study is designed to determine whether the ILI students like to be corrected or not. In addition, it is going to determine the relationship between the ILI English learners' perceptions about oral error corrections and their gender. Reviewing the literature, I hypothesize that the ILI English learners have positive attitudes towards oral error corrections. I, also, think that there is not a significant relationship between the ILI English language learners' perceptions towards oral error corrections and their pronunciation accuracy. Writing about the third question, I guess there is no significant relationship between the ILI English language learners' perceptions towards oral error corrections and their gender.

\section{Method}

\subsection{Participants}

Eighty-two (44 females, 38 males) English language learners studying English at Iran Language Institute (ILI) in Khorramabad, Lorestan, Iran, participated in this study. The participants were all from Khorramabad, so their mother tongue was either Farsi or Lorish. In terms of age, they mostly ranged from fourteen to thirty. And in terms of level of education, twenty-nine of them were college students, and fifty- three were junior or senior high school students. Regarding sampling, the participants were chosen in the form of clusters, and it was tried to choose the learners whose English language knowledge was almost the same, so the learners who were studying at elementary levels (EL1, EL2, and EL3) were chosen for this study. All in all, sixty-one of the participants had passed or were studying EL1; the others were studying either EL2 or EL3.

\subsection{Materials}

In this study, in order to get participants' perceptions about classroom oral correction, an adopted and adapted questionnaire was used. The original questionnaire was developed in English after extensive literature review, and it was used by Katayama (2007). The questionnaire contains four sections. The first section contained demographic information. The second section addressed Research Question 1 and asked the participants' general opinions about the correction of oral errors in the classroom. This section contained four statements illustrating certain views that have been controversial among language researchers and educators for decades. These views included: whether or not learner errors should be corrected; when learner errors should be corrected (i.e., constantly or selectively); and who should correct errors, teachers or peers. The participants were asked to indicate their degree of agreement or disagreement with four different statements. Response options were coded to 5-point scales, with 1 representing strongly disagree and 5 representing strongly agree. The participants were given the option of explaining the reasons for their rating in order to provide this research with "useful/insightful" qualitative data (Nunan, 1992, p. 145). The third section asked about participants' preferences for classroom error corrections of different aspects of the language. The participants were asked how often they wanted classroom error correction of different types of errors: grammar, phonology, vocabulary, pragmatics, and discourse. Instead of the term phonology, the words" pronunciation, accent, and intonation" were used in the questionnaire. Errors in pragmatics were presented as "inappropriate expressions," and discourse errors as "organization of discourse." Participants rated each item on a 5-scale, with 1 representing never and 5 representing always with respect to frequency of correction. The last section asked about participants' preferences for particular types of error correction methods. The participants were asked to rate different methods of error correction provided by teachers, first as feedback to students' grammatical errors, and then as feedback to students' pronunciation errors for each technique. Examples of errors were presented in the questionnaire. The rating for students' opinions about each method was measured on a 5 -scale, ranging from 1 representing no good to 5 representing very good. In order to prevent any misunderstandings from participants' behalf, the questionnaire was translated into Farsi. The adopted questionnaire contained four sections. The first section was used to elicit demographic information. The second, the third, and the fourth sections were used to direct the main question of the study- students' perceptions towards classroom oral error correction. In order to get necessary information about the participants' pronunciation accuracy, a teacher-made test which contained twenty words which were all from Elementary 1 book and were supposed to be problematic in terms of pronunciation and had already been taught to all participants was given to the participants to read aloud. In order to be sure that the test was valid, it was given to 40 language learners, some of whom had studied and passed Elland some had not, which showed the participants who had passed Ell got much higher marks than the ones who had not, which confirmed that the test was valid. Then, I got some experienced teachers and professors' opinions on the test. They, also, confirmed that the test could be a valid measure of pronunciation accuracy. 


\subsection{Procedures}

To get participants' perceptions towards classroom oral corrections, the questionnaires were given class by class; then, they were marked by giving 5 points to strongly agree and always choices, 4 points to agree and most of the time choices, 3 points to uncertain choices, 2 points to disagree and sometimes choices, and 1 point to strongly disagree and never choices. The points were added up for each perception questionnaire; the mark was divided by 9 to get the mean for each questionnaire. The mean could range from 1 to 5 . In terms of attitudes, the means which were above 3 (mean $>3$ ) were taken positive; the ones which were below 3 (mean $<3$ ) were taken negative, and the ones which were 3 (mean $=3$ ) were taken neutral. Then distribution frequency was calculated to find out how many participants got more than 3, having positive attitude, how many got less than 3 , having negative attitude, and how many got 3 , being neutral. Distribution frequency was also used to determine whether participants, all in all, had positive or negative attitudes towards classroom oral error corrections. To find out whether there was a relationship between gender and the participants' attitudes, the means of the marks of the perception questionnaires for males and females were calculated separately; in order to find out, if there was any difference, the males and the females' means were compared, then t-test formula was used to see whether the difference was significant or not. Writing about pronunciation accuracy, I gave the pronunciation test to the participants through which they were asked to read aloud the twenty words which were all from elementary 1 book. It was done one participant at a time. In fact, the words were added to the perception questionnaire, so I could put an $\mathrm{x}$ next to the words which were pronounced inaccurately. Then the pronunciation tests were marked by taking one point away for every mispronunciation. The participants' marks were out of twenty. In order to find out whether there was a relationship between participants' perceptions towards oral error corrections and their pronunciation accuracy, both their perception and pronunciation scores were correlated by using Pearson's product moment correlation coefficient.

\section{Analyses}

After giving the perception questionnaires and pronunciation tests to the participants and marking them, frequency distribution was calculated to find out how many participants got more than 3 , how many less than 3 , and how many 3 on the perception questionnaire test, which showed most of the participants got more than 3 , which meant participants' positive attitudes towards classroom oral error corrections. Calculating the mean and the standard deviation for both the perception questionnaire scores and pronunciation test scores, I used Pearson product moment correlation coefficient to get the relationship between participants' perception scores and their pronunciation scores, which showed no relationship because $r_{\text {observed }}<r_{\text {critical }}$ at $a=0.01$. By calculating the means and standard deviations for male and female participants' scores on perception questionnaire separately, the researcher found out that the females' mean of perception scores was higher than that of males. To get whether the difference was significant or not $t$-test formula was used, which showed that $t$ observed $(0.057)$ was smaller than $\mathrm{t}_{\text {critical }}(2.660)$ at $\mathrm{a}<.01$, and it was smaller than $\mathrm{t}_{\text {critical }}(2.000)$ at $\mathrm{a}<0.05$ with $\mathrm{df}=80$.

\section{Results}

Frequency distribution (table 1) showed that the participants had positive attitudes towards classroom oral error corrections; as you can see in table1, more than 91 percent ( 75 participants) scored above 3 on perception questionnaire, which meant they liked to be corrected. Only 4.87 percent (4 participants) scored below 3 and had negative attitudes towards classroom oral error corrections. As it is shown in the table 3.6585 percent (3 participants) got 3 and had neutral attitudes, which meant they had neither positive nor negative attitudes towards classroom oral error corrections.

Table 1. Frequency distribution of participants' perceptions towards classroom oral error corrections

\begin{tabular}{lll}
\hline Perception & Frequency & Percentage \\
\hline Positive (greater than 3) & 75 & 91.4634 \\
Negative (smaller than 3) & 4 & 4.878 \\
Neutral(3) & 3 & 3.6585 \\
Total & 82 & 100 \\
\hline
\end{tabular}

Using descriptive statistics and calculating Pearson product moment correlation coefficient, as it is shown in table 2, I could say that there was not any significant relationship between participants' perceptions towards classroom oral error corrections and their pronunciation accuracy. As it is shown in table $2, \mathrm{r}$ observed $(0.056)$ at $a=0.01$ with $d f=80$ is smaller than $r_{\text {critical }}(0.2830)$, so null hypothesis is confirmed, which means there is not any 
relationship between participants' perceptions towards classroom oral error corrections and their pronunciation accuracy.

Table 2. Descriptive statistics of pronunciation test scores and perception questionnaire scores

\begin{tabular}{llll}
\hline & Mean & Standard deviation & Number of Participants \\
\hline Pronunciation Scores & 13.8049 & 3.04063 & 82 \\
Perception Q Scores & 3.9630 & 0.55063 & 82 \\
Pearson Product Moment Correlation Coefficient & -0.054 & \\
Significance & 0.629 & \\
\hline
\end{tabular}

Using t-test formula to calculate the amount of $\mathrm{t}$, as it is shown it table 3, I could say that the variable of sex did not have any significant relationship with participants' perceptions towards classroom oral error correction because $\mathrm{t}_{\text {observed }}(0.70)$ was smaller than $\mathrm{t}_{\text {critica }} \mathrm{l}(2.660)$, two-tailed, at $\mathrm{a}=0.01$ with $\mathrm{df}=80$.

Table 3. Males and females' means of scores on perception questionnaire, standard deviation, and $\mathrm{t}$

\begin{tabular}{lllll}
\hline & Mean & Standard Deviation & T & Degrees of Freedom \\
\hline Male & 3.9166 & 0.64964 & 0.70 & 80 \\
Female & 4.0032 & 0.45213 & & \\
\hline
\end{tabular}

\section{Discussion}

Regarding the first question, it can be seen, as it is shown in frequency distribution table, that the ILI students have positive attitudes towards classroom oral error corrections. The participants have the perception mean of 3.9667 which is interpreted as positive, and most of them want to be corrected whenever they make mistakes, which is line with findings of a study done by Katayama (2007) in Japan. The reason for this, as the participants provided in the questionnaires, is that they do not want to repeat a mistake on and on. They, also, want to speak English as accurately as possible. The other reason which was provided by the participants in the questionnaire is that they do not want to have incorrect knowledge. As for the second question, the relationship between the ILI students' perceptions towards classroom oral error corrections and their pronunciation accuracy, the results show that there is not any significant relationship between them. One reason, maybe, is that the students give different amount of importance to pronunciation accuracy, or maybe, pronunciation is not seen as an important sub-skill as vocabulary and grammar. In terms of the third question, the relationship between gender and participants' perceptions towards classroom oral corrections, the results show that there is not any relationship between them, so gender does not have any effects on the participants' perceptions towards classroom oral corrections. The reason why males and females' perceptions are not so different is, maybe, that males and females in Iran are taught exactly in the same way and are taught the same subjects.

\section{Conclusion}

Language learners' attitudes about classroom oral error corrections, the effect of gender on their attitudes, and the relationship between their attitudes towards classroom oral error corrections and their pronunciation accuracy were the subjects studied in this paper. The results show that language learners want and like to be corrected. Learners "gender does not have any effects on their attitudes towards classroom oral error corrections. Writing about the relationship between learners" attitudes towards classroom oral error corrections and their pronunciation accuracy, I could not find any significant relationship. You must bear in mind that almost every study has some limitations. This study is not an exception, so it has its own limitations. I must confess that, while doing this research, the participants' age and their level of education were not taken into account; I mean they were not the same age, and they were different in terms of knowledge, and all participants' families were ok in terms of economical and social status; I mean poor students were not included because not all families can afford to send their children to the ILI to learn a foreign language, so while generalizing, you must be very careful. There are still subjects in this area which need further research: the relationship between age and language learners' perceptions, the relationship between learners' level of education and their perceptions towards errors and error corrections in general, and the relationship between learners' perceptions towards errors and error corrections and their language achievement in general. 


\section{References}

Bidin, S. (2009). Motivation and Attitude in Learning English among University Teknologi MARA Students in the Northern Region of Malaysia. English Language Teaching, 2(2). http://dx.doi.org/10.5539/elt.v2n2p16

Browen, H. D. (2000). Principles of Language Learning and Teaching (4th ed.). White Plains, vii, 352.

Cathcart, R. L., \& Olsen, J. W. B. (1976). Teachers and Students' Preferences for Correction of Classroom Conversation Errors. In J. F. Fanselow \& R. H. Crymes (Eds.), On TESOL, 76, 41-45.

Fakeye, D. (2010). Students' Personal Variables as Correlates of Academic Achievement in English as Second Language in Nigeria. Journal Social Science, 22(3), 205-211.

Hawkey, R. (2006). Teacher and Learner Perception of Language Learning Activity. ELT Journal, 60(3), 242-252. http://dx.doi.org/10.1093/elt/ccl004

Horwitz, E. K. (1988). The Beliefs about Language Learning of Beginning University Foreign Language $\begin{array}{lllll}\text { Students. } & \text { The Modern }\end{array}$ http://dx.doi.org/10.1111/j.1540-4781.1988.tb04190.x

Inal, S., Evin, I., \& Saracaloglu, A. S. (2009). The Relationship between Students' Attitudes towards Foreign Language and Foreign Language Achievement.

Katayama, A. (2007). Learners' Perceptions toward Oral Error Correction. In K. Bradford-Watts (Ed.), JALT 2006 Conference Proceeding. Tokyo: JALT.

Kiptui, D. K., \& Mbugua, Z. K. (2009). Kenya Journal of Education, Planning, Economics and Management (vol. 1). Kisumu: Education Management Society of Kenya.

Lasagabaste, D., \& Sierra, J. M. (2005). Error Correction, Students' versus Teachers' Perceptins. Language Awareness, 14(2), 112-127. http://dx.doi.org/10.1080/09658410508668828

McCargar, D. F. (1993). Teacher and Student Role Expectations: Cross-cultural Differences and Implications. The Modern Language Journal, 77(2), 192-207. http://dx.doi.org/10.1111/j.1540-4781.1993.tb01963.x

Mellet, S. M., \& Crowe, J. H. (2009). The Relationship Between Selected Affective Factors and Achievement in English of Secondary Students in Zimbabwe. Institutional Repository.

Nunan, D. (1987). Communicative Language Teaching: the Learners' View. In K. D. Bikram (Ed.), Communication and Learning in the Classroom Community (pp. 176-190). Singapore: SEAMEO Regional Language Center.

Nunan, D. (1988). The Learner-centered Classroom. Cambridge: Cambridge University Press.

Nunan, D. (1992). Research Methods in Language Learning. Cambridge: Cambridge University Press.

Nunan, D. (1995). Closing the Gap Between Learning and Instruction. TESOL Quarterly, 29(1), 133-158. http://dx.doi.org/10.2307/3587808

Oladejo, J. A. (1993). Error Correction in ESL: Learners' Preference. TESL Canada Journal, 10(2), 71-89. http://dx.doi.org/10.18806/tesl.v10i2.619

Schulz, R. A. (1996). Focus on Form in the Foreign Language Classroom: Students and Teachers' Views on Error Correction and the Role of Grammar. Foreign Language Annals, 29(3), 343-364. http://dx.doi.org/10.1111/j.1944-9720.1996.tb01247.x

Schulz, R. A. (2001). Cultural Differences in Student and Teacher Perceptions Concerning the Role of Grammar Instruction and Corrective Feedback: USA Columbia. The Modern Language Journal, 85(2), 244-258. http://dx.doi.org/10.1111/0026-7902.00107

Scott, K. W., Bell, S. M., \& MacCallum, R. S. (2009). Relation of Native Language and Spelling Abilities to Attitudes Towards Learning Second Language. Preventing School Failure Alternative Education for Children \& Youth, 54(1), 30-40. http://dx.doi.org/10.3200/PSFL.54.1.30-40

Tracy, B. (1997a). Great Little Book on Personal Achievement. Carol Publishing Group, U.S.

Tracy, B. (1997b). Great Little Book on Universal Laws. Wayne, NJ: Career Press. 


\section{Copyrights}

Copyright for this article is retained by the author(s), with first publication rights granted to the journal.

This is an open-access article distributed under the terms and conditions of the Creative Commons Attribution license (http://creativecommons.org/licenses/by/4.0/). 